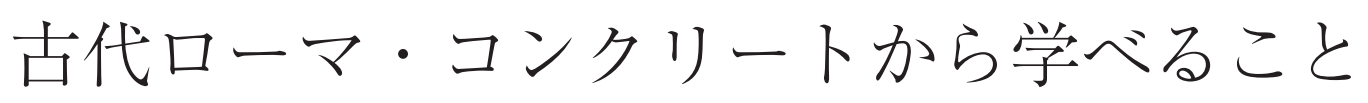

久田真*

1.はじめに

21 世紀を前後する時期に，古代ローマ・コンクリート に関する様々な調査，検討を進める機会を得た。その間， コンクリートの歴史研究に関する大先駆である故 小林一 輔博士の著作「コンクリートの文明史 ${ }^{1} 」 に$ 学び, 先生の ご生前に直接ご意見を抨聴することができた。また，我 が国における古代ローマ史研究の第一人者である青柳正 規博士（国立西洋美術館館長）からは，古代ローマ人の 気質やものづくりに対する考え方などをご教示頂くこと もできた。さらに，青柳博士のご厚意により，イタリア・ ナポリのヴェスヴィオ火山近郊で, 現在もな抢発掘中の ソンマ・ヴェスヴィアーナ（Somma Vesuviana）遺跡 から貴重なコンクリートサンプルを頂戴し，これらを調 査分析するという幸運にも恵まれた。なお，これらの一 連の調査研究活動には, 前田又兵衛博士 (前田建設工業) のご支援のお蔭もあった。

本稿は, 「不易流行」の観点から, 筆者が古代ローマ . コンクリートの調查研究活動を通じて学んだいくつかの 事項を紹介するとともに, 今般の東日本大震災の復旧や 復興に扔いても，古代ローマ・コンクリートを通じて得 られる様々な知恵を応用することがいかに重要であるか を概説した。

2. 我が国における古代ローマ・コンクリートの 調查事例

イタリアの首都であるローマ市の市街地にあるフォ ロ・ロマーノやカラカラ浴場, コロッセオなどは, 古代 ローマ・コンクリートと称されるセメント系の硬化体が 大規模に残されている場所として良く知られている。し かし, 古代ローマ・コンクリートを製造する際に不可欠 な材料であったポッツォラーナ（pozzolana）が, イタ リア中部の中核都市ナポリ（Napoli）近郊にあるヴェス ヴィオ火山（Vesuvio）からの噴出物を起源としている ことままたナポリ近郊にはポッツォーリ（Pozzuoli） と呼ばれる場所があり，この地から採取されるという経 緯からこの名がついたとされることから, 古代ローマ. コンクリートの技術の源流は, 中部イタリアにあると考 えてもそれほど間違いではないと思われる。

* ひさだ・まこと/東北大学大学院 教授 (正会員)
また，図-1に示したとおり，世界遺産としても著名 なポンペイ (Pompei) 遺跡とエルコラーノ (Ercolano) 遺跡，また，現在発掘中のソンマ遺跡にあるほとんどの 建造物が古代ローマ・コンクリートと称される素材で構 築されている。これらの遺跡はいずれもヴェスヴィオ火 山を取り巻くように位置しているが，ポンペイやエルコ ラーノは、コムーネ (comune) と呼ばれる基礎自治体 を構成する集落で, その起源は古代ローマ時代以前に遡 る。したがって, 古代ローマ・コンクリートの技術は, すでに 2000 年以上も前に開花したと考えてよい。

古代ローマ・コンクリートに関する調查研究は, 欧米 を中心に現在も活発に行われているが，我が国で実施さ れた事例としては，社土木学会が 2003〜2009 年にかけ て実施した調查研究活動 2 が挙げられる。本調查は, 東 京大学を中心として展開された「ソンマ・ヴェスヴィ アーナ，ローマ時代遺跡調査プロジェクト（リーダー： 青柳正規博士)」のうち, 古代ローマ・コンクリートに 関する文献整理をはじめ, 実際に採取された古代ロー マ・コンクリート試料の分析や，これらの結果に基づい て古代ローマ・コンクリートを再現し，その諸物性に関 する検討を行ったものである。詳細は参考文献 2) およ び3）に譲るが，本調査の目的の一つには，原子力発電 所から排出される放射性廃棄物の長期保存手段として使 用されるコンクリートの耐久性評価のための情報収集が あった。その背景には, 現在我々が日常的に使用してい るポルトランドセメントが発明されて以来，いまだに 2

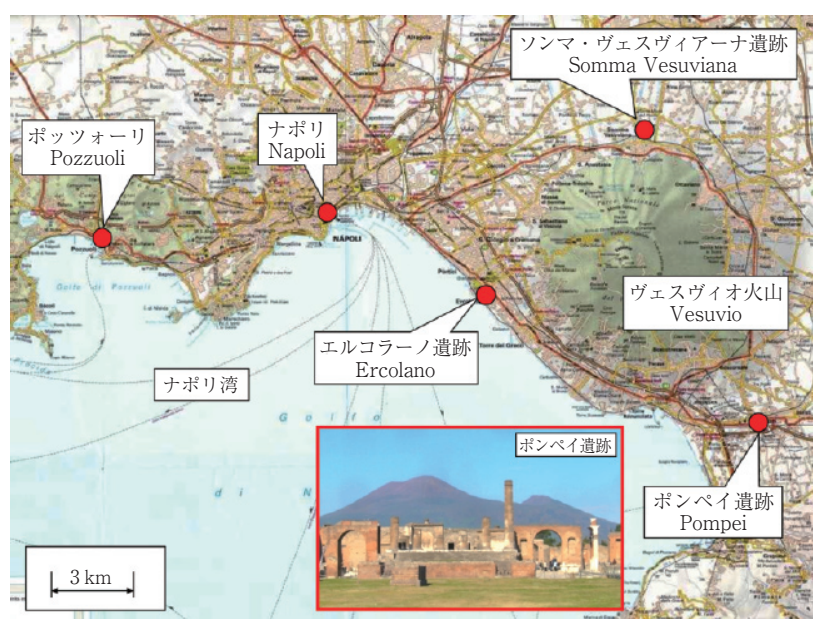

図-1ナポリ近郊の地図 
世紀にも満たず，数千年〜数万年という長期にわたる材 料の評価には，古代ローマ・コンクリートを対象とした 調查に頼らざるを得なかったという事情がある。古代 ローマ・コンクリートに使用されたセメントとJ. Aspdin（英）の発明したセメントは製造方法が異なり， 施工方法には歴史的な変遷が認められるものの, 水, 結 合材，骨材と少しの混和材料という材料構成を用いてこ れを十分に締め固め，入念な養生を経て堅牢かつ耐久的 な建造物を構築するという点は不変である。この点はや はり，コンクリート技術に扔ける「不易流行」の一つと 考えることができるであろう。

\section{3. 学ぶべき古代ローマ人の知恵}

\section{1 要求性能に応じたコンクリートの利用}

先述の土木学会の調查では, ソンマ遺跡で入手した大 型試料を日本へ搬送し，これから採取したコンクリート 試料の力学的性質を調べた。まず, 大型試料を切断し, 断面を観察したところ, 写真-1 に示すように 3 層から 構成されていることが分かった。3 層はそれぞれ，写真 上側から粗骨材としてレンガ片を多く含む層（第 1 層）, レンガ以外に石灰石なども比較的多く含み, マトリック 又部分が白く見られる層 (第 2 層)，㧍よび粗骨材とし て比較的大きな黄色凝灰岩を含み, マトリックス部分が 暗色である層（第 3 層）として区分できた。なお，発掘 現場の考古学専門家によれば, この試料のコンクリート は屋根の一部であり，第 1 層側が屋外側で第 3 層が室内 側であるとのことであった。な技，土木学会の調查では， 大型試料から採取したコア強度は, 第 1 層が最も大きく, ち密な構造体であることが判明している2)。

この大型試料が実際に屋根に使用されていたとする と, 我々が推測できるのは, 直接降雨が作用する第 1 層 のコンクリートに要求されるのは防水性であり, 室内側 となる第 3 層のコンクリートには，断熱性や軽量である ことなどの品質が要求されるということである。すなわ ち古代ローマ人は, コンクリートに用途に応じて要求性 能を設定し，それぞれに品質の異なるコンクリートを使 い分けていたということが推察される。このことは, 性 能規定に基づく現代のコンクリート技術にも直結する考 え方である。

\section{2 リサイクルと末利用資源の有効活用}

写真-1に示したコンクリートの断面では, 第 1 層の コンクリートには, レンガを骨材として使用しているこ とが分かるが，これらのレンガは，仕上げ壁に使用され たレンガのかけらや, 壊れた土器をリサイクルして利用 したと推察できる。また, 写真-2 は, 古代ローマ・コ ンクリートの近接画像であるが, これによれば, 古代 ローマ人は, レンガ片の他にも，大理石やヴェスヴィオ 火山から噴出した溶岩の破砕片をも骨材として使用して いた痕跡とみることができる。

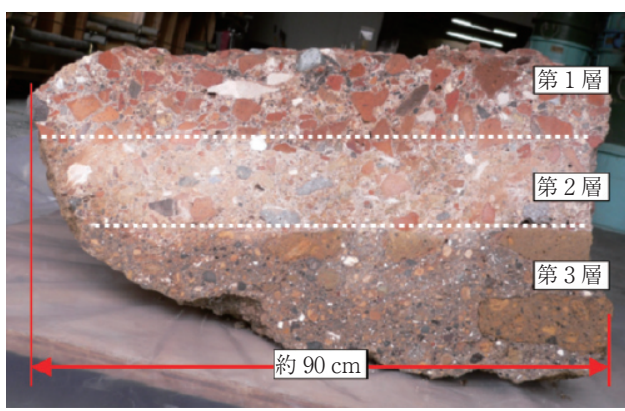

写真-1 古代ローマ・コンクリートの切断面の状態 (土木学会による調查のために日本に運搬された試料)

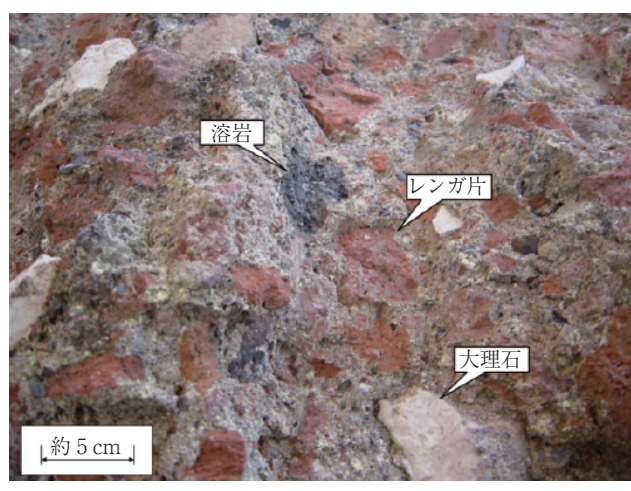

写真-2 古代ローマ・コンクリートの近接画像 （硬化体中に様々な材料の混入が確認できる）

確立した技術として成立する前には，相当の時間を要 したかもしれないが，コンクリートの骨材としてレンガや 土器の破片を利用することは, 今日の我々が再生骨材コン クリートを製造する発想と相通ずるものであろう。また, 大理石や溶岩の破砕片を骨材として使用するという発想 も，今日の我々の技術になぞらえれば，スラグや石炭灰， クリンカアッシュなどの未利用資源を有効活用する取組み に近いものである。しかも，当時はJIS のような厳格な品 質規格があるとは考えにくく，製造されたコンクリートが 所要の性能を満足していれば, 使用する材料には制約を設 けていなかったのではないかとすら考えることも可能であ ろう。すなわち, 品質要件として密度や吸水率が多少規格 外な骨材を使用したとしても, 品質の確かなコンクリート を製造することこそ技術なのであり，このことはリサイク ル材料や未利用資源を工夫して使いこなすことの重要性を 示唆しているのではないか，と考えることができる。

\section{3 コンクリートの施工法}

今日のコンクリート製造技術に扔いても，コンクリー トの粗骨材の最大粒径は, 用途に応じて可能な限り大き いものを選定することが基本である。被災地に打けるが れきの処分と有効利用にあっても，例えばコンクリート がれきなどは，洗浄し，分級して現行の JIS に準拠した 汎用性のある材料とするよりも，それほど細かく破砕し ないで，大粒径のままの状態で使用できれば，経済性や 処理速度の観点から有利になることが考えられる。

図-2は，小林博士の著した「コンクリートの文明史」 

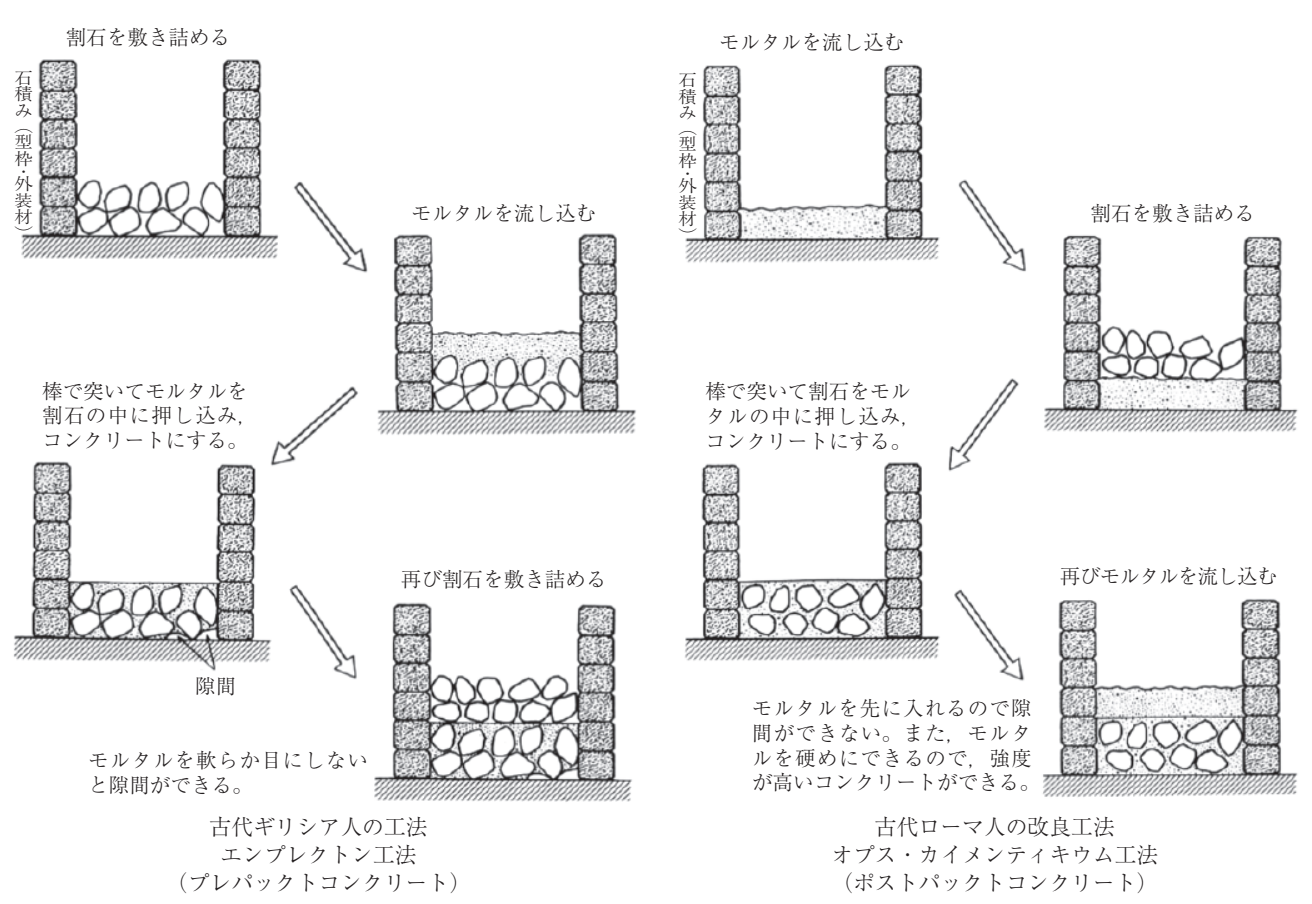

図-2 コンクリート施工法の比較

（岩波書店）に記された古代ギリシア人のコンクリート の施工法とローマ人のそれとを比較したものである。古 代コンクリートの先達であるギリシア時代には，まず巨 石骨材を敷き均し，その間隙にモルタルを流し込んで構 築するという，今日でいうプレパックトコンクリートの 施工法で構造物を構築していた。しかし，今日のように モルタルを十分に流動化させる薬剤がなかったため,こ の工法では，十分に気泡を除去させることができなかっ た。これに対して，古代ローマ人は，モルタルを先に敷 き均し，その後に骨材を投入するポストパックトコンク リートとすることにより，気泡の介在を回避したのである。 硬化体には余分な間隙を残留させないようにするとい う原則を踏襲し，前例にとらわれず，より合理的な新し い技術も開発する，という精神は，まさに「不易流行」 といえるのではないだろうか。

\section{4 粘り強い維持管理}

写真-3 は, ポンペイ遺跡のとある住居の壁の状況で ある。一見したところ，何の変哲もない壁であるが，良 く見ると, 複数の修復の痕跡が見受けられ，しかも修復 の跡は一様ではなく，年代を経て様式が異なっているこ とが分かる。このような痕跡から，古代ローマ人は，老 朽化した家屋を取り壊すことなく，何百年，何千年とい う歳月にわたって補修を繰り返し, 粘り強く維持管理し ていたと推察することができるのではないだろうか。

古代ローマ人にアセットマネジメントやライフサイク ルコストといった概念があったかどうかは定かではない が，例えばアッピア街道など，自分の名前を冠したイン フラがそう簡単に老朽化させてしまうわけにはいかない ので，インフラの耐用年数などは「永遠」と考えていた のではないか, とも推測することは可能である。ともあ

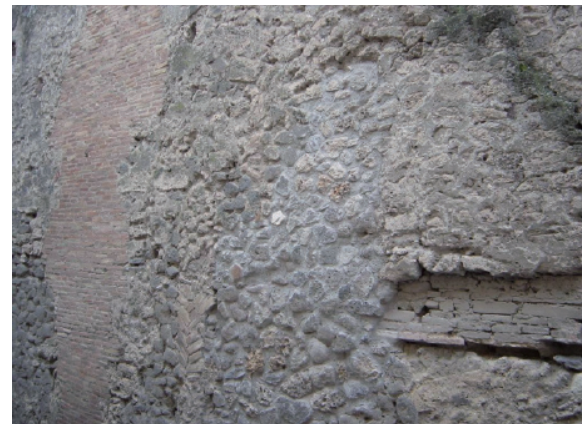

写真-3 数百年にもわたって繰り返された補修の跡 (ポンペイ遺跡にて)

れ，使えるものは徹底的に利用し，補修するにあたって も費用負担を最小限にし, 新しい補修技術が開発されれ ばその技術を躊躇なく利用するといった，大胆かつ柔軟 な発想は持っていたのであろうと考えられる。

少なくとも筆者は，とてつもなく長い期間にわたって 繰返しの補修を実施すれば，その履歴ですら一つの歴史 となり, 先人の維持管理の痕跡が後世の人々にものづく りの考え方や技術として継承され，省みられるものた と，この何の変哲もない壁を見て思ったのである。

\section{5 都市の持続と再生}

読者の多くが知っているとおり, 歴史都市ローマに は，地下遺跡と呼ばれる観光名所が点在している。これ は，数千年の歴史を持つローマという都市が，過去の街 並みを埋立て，嵩上げすることによって新たな都市を建 設した所作である。当時の支配者にしてみれば，旧市街 地を埋め立てて新しい都市を築くという行為は，過去の 都市を払拭することによって，自らの権威を示すためで もあったであろうが，地下に眠る旧市街地と現代の人々 が暮らしている市街地との比較において，極めて興味深 


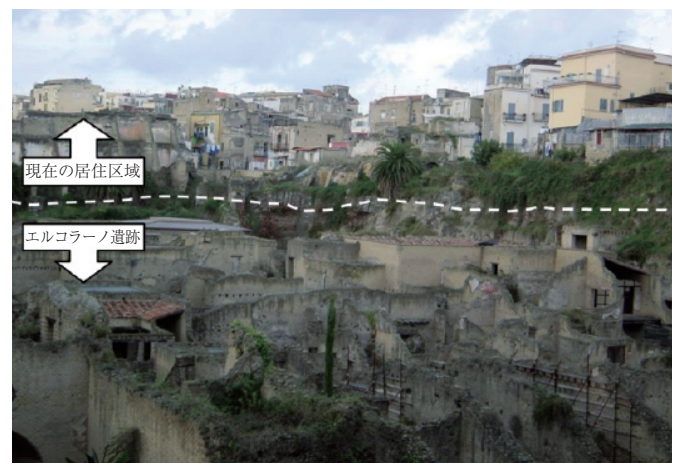

写真-4 エルコラーノ遺跡と近隣の住居

い光景がエルコラーノ遺跡にある。

エルコラーノ遺跡は, ポンペイ遺跡と同様, A.D. 79 年のヴェスヴィオ火山の噴火により埋没したコムーネで あるが, 写真-4は, 今も発掘作業が続けられている工 ルコラーノ遺跡の状況を示したものである。説明のため に破線と凡例を施してあるが, 写真-4のとおり, 遺跡 の街並みと現代の住居との差異がほとんど見受けられな いのである。確かに, 現代の街並みでは, 道路はアス ファルトで作られ, 自動車が往来し, 電柱や電線は張り 巡らされ，それぞれの家屋の屋上にはテレビのアンテナ が立ち並んでおり，当然ではあるが，これらの現代文明 の利器は, 遺跡には存在しない。しかし, 街並みが放つ 雲囲気には，大きな差が感じられず，極言すれば，街が 同じ顔をしているような感覚を持つのである。

何千年にもわたって, イタリアのこの地に住む人々は, 子々孫々，エルコラーノというこの都市に住み続けてい るのだろう。A.D. 79 年に噴火したヴェスヴィオ火山の ふもとに位置するこの都市は，いまでも噴火の危険性を 孕んでおり，そこに住む人々はそれでも決して離れよう としない。筆者が聞いた話では，噴火の危険性があるた め，行政上はこの地に住むことは認められていないらし く, 万が一, 被災に遭ってもナポリ政府は救済しないと まで言われているとのことであるが，それでも人々はこ の地に住む。それほど, この地は風光明媚で, オレンジ や魚介などの食べ物もワインも他の地に替え難いほど美 味しく, 人々は大らかで, 陽気で, 吞気である。都市の 持つ歴史, 重み, 愛着とは, こういうものか, と痛感し たものである。

4.おわりに〜古代ローマ人の知恵は震災復興に も活かせる!〜

東日本大震災からまもなく 2 年が経過しようとしてい る。この間, 被災地の一つに身を置く立場にあって, 機 に応じて古代コンクリートの調査研究から学んだ事項を 想起することがしばしばあり，がれきの処分・有効利用 をはじめ, 震災からの復旧, 復興に関して参考になるこ とが少なくない。

例えば，巨石骨材を用いたプレパックトコンクリートや

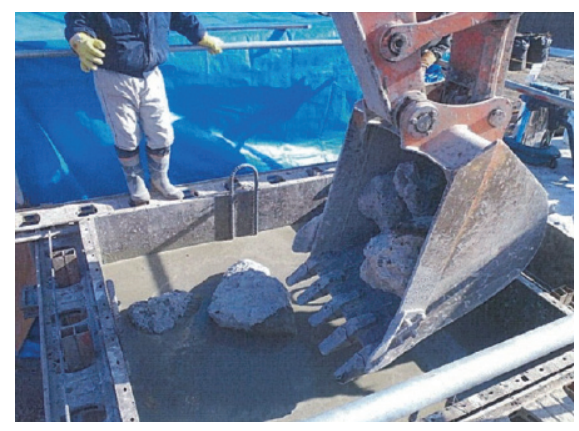

写真-5 大粒径コンクリートがれきを使用したポストパックト コンクリートによる漁礁ブロックの施工例 （岩手県宮古市田老地区，写真提供：水産庁）

ポストパックトコンクリートによる施工法は, 今回の震 災復旧工事において，コンクリートがれきを再生骨材の ように入念に分級, 洗浄することなく, 大粒径 $\left(G_{\max }=\right.$ $300 \mathrm{~mm}$ 程度）のまま使用し，漁場ブロックを構築した 事例 ${ }^{4)}$ があるが，これもいわば古代ローマ人の知恵を復 興に活かした事例であるといえよう（写真-5）。

現在, 復旧, 復興事業における急激な需要のため, 被 災地ではコンクリート用骨材やレディーミクストコンク リートのほか, 盛土用土砂などが極端に不足している状 況となっている。この需要に応えるために, 沈下した地 盤の嵩上げや盛土には，コンクリートがれきや津波堆積 土砂を積極的に使用すべきであると思う。さらに，ある 程度の品質条件を満足すれば，スラグや石炭灰，クリン カアッシュなどの未利用資源も積極的に有効活用し, JIS を満足するような高品質の天然資源は, 我が国の天 然資源の温存という視点も持ちながら，しかるべき構造 物の構築の方で利用するなど，大局を鑑みながら適材適 所に材料を利用するという，これまた古代ローマ人の知 恵を活用すべきであると考えている。

安全安心の確保が前提にはなるものの, 津波によって 壊滅的なダメージを受けた被災地の復興にあたっても, 都市の再生というものが，果たして費用便益や経済効果 などの合理性のみを追求することで合意形成ができるの か, 古代ローマから学ぶとすれば，その都市の持つ歴史 や愛着なども復興には考慮されるべきではないか, と思 うところが多い。

古代ローマ・コンクリートの「不易流行」は，今日に おいても煌々と光を放っていると感じて止まないが…… 逆の見方をすれば，この 2000 年の間に，コンクリート 技術は，一体，何が進歩したのだろうか？

\footnotetext{
参考文献

1）小林一輔：コンクリートの文明史，岩波書店，2004

2）土木学会編：古代ローマ・コンクリート〜ソンマ・ヴェスヴィ アーナ遺跡から発掘されたコンクリートの調査と分析〜, コンク リートライブラリーNo.131, 2009

3) 中野定雄・中野里美・中野美代 訳：プリニウスの博物誌, 第盀卷, pp.1488 1489, 雄山閣, 第 6 版, 2001

4）水産庁：漁場施設への災害廃棄物等再生利用の手引き, 2012.7
} 